$12-15-2015$

\title{
Human Rights States and Societies: A Reflection From Kenya
}

Willy Mutunga

Follow this and additional works at: https://digitalcommons.osgoode.yorku.ca/thr

Part of the Human Rights Law Commons

\section{Citation Information}

Mutunga, Willy. "Human Rights States and Societies: A Reflection From Kenya." The Transnational Human Rights Review 2. (2015): 63-102.

https://digitalcommons.osgoode.yorku.ca/thr/vol2/iss1/3

This Article is brought to you for free and open access by the Journals at Osgoode Digital Commons. It has been accepted for inclusion in The Transnational Human Rights Review by an authorized editor of Osgoode Digital Commons. 


\section{HUMAN RIGHTS STATES AND SOCIETIES: A REFLECTION FROM KENYA}

\section{WILLY MUTUNGA*}

A human rights state is conceptualized as a liberal democratic state with a social democratic content, the modern day version of the capitalist welfare state. With the "collapses" of communism and neoliberalism, the paradigms of human rights and social justice have taken a center state. The birth of transformative constitutions and transformative constitutionalism linked to modern and comprehensive Bills of Rights have enriched the intellectual, ideological, and political debates of human rights and social justice paradigms. On one hand they have the ingredients of mitigating neo-liberalism while on the other hand they reflect some of the features of the paradigms that critique neoliberalism. Social democracy has thus become the basis of the search for a liberating paradigm in the context of the global order. In this article the conceptualization of human rights state, currently under-theorized, is undertaken. Kenyan transformative Constitution and its development of transformative constitutionalism is the practical case study in this inquiry. The theoretical and practical approach adopted in the article remains politically plausible to the interrogation of the critical contemporary question, namely, whether the paradigms of human rights and social justice can be the basis of fundamental restructuring of societies in the Global South.

\section{STATES THAT ARE COMMITTED to the implementation of new-framework} constitutions, within the framework of transformative constitutionalism, ${ }^{1}$ understand that historicizing and problematizing human rights and social justice are critical to real change. The uses and limitations of the human rights and social justice paradigms and discourses have particularly engaged leftist scholars and activists since the collapse of the Berlin Wall in 1989. Social democracy became the subject of deep inquiry as many in the left rejected neoliberalism's view that the ideological paradigms of socialism and communism had been buried in the rubble of the Berlin Wall. Social democracy became the non-dogmatic basis of reflecting upon the paradigms of that underpinned both neo-liberalism and socialism/communism. Many

\footnotetext{
* LL.B, LL.M (Dar), D, Jur (Osgoode Hall Law School) Chief Justice \& President of the Supreme Court, Republic of Kenya. I thank Professors Jill Ghai, Yash Ghai, Makau Mutua, Joel Ngugi, Roberto Gargarella, and Joe Oloka Onyango; as well as Albie Sachs and Duncan Okello for their brilliant comments on earlier drafts of this article.

${ }^{1}$. Karl Klare argues "transformative constitutionalism connotes an enterprise of inducing large-scale social change and through non-violent political processes grounded in law." This article will endorse this argument while rescuing it from its limitations.
} 
leftists were rightly of the view that there was great need to interrogate not only what had actually collapsed in the former Soviet Union, China, Albania, and Eastern Europe, but also critical lessons of what should be preserved, nurtured, and developed as the search for the liberating paradigm/s continued. That inquiry and interrogation continues.

Human rights and social justice paradigms and discourses, which are reflections of social democracy, became part of this inquiry. The ensuing struggle for transformative constitutions was partly about the implementation of a social democratic vision of a society, as the Kenyan case study illuminates. The argument seemed a political one -- that social democracy could mitigate the limitations, traumas, weaknesses, and inhuman edges of a liberal democracy.

However, despite this ferment, this quest for transformative constitutionalism, there is no doubt that the concept of a human rights state has continued to be under-theorized and conceptualized. But what is a human rights state? Could such a state midwife a social democratic state and society? Could it be the basis of completing the "unfinished" revolution or could it reinforce the status quo in liberal democratic societies? Could it conceptually assist in interrogating, historicizing, and problematizing the various dominant theoretical paradigms today? Similar questions have faced the World Social Forum ${ }^{2}$ since some of its membership imagines a new world that is possible through human rights and social justice's ideological, intellectual, and political lenses. The inquiry and interrogation continues.

This article presents the Kenyan case study for comparative scrutiny and interrogation. Studies from India, South Africa, Bolivia, and Colombia, for example, are useful because those countries are, to varying degrees, implementing transformative constitutions. They have also been significant developers and shapers of international human rights jurisprudence and

2 .Tom Metes, ed, A Movement of Movements: Is Another World Really Possible? (New York: Verso, 2004); Jai Sen et al, eds, World Social Forum: Challenging Empires (New Delhi: Viveka Foundation, 2004); Jose Correa Leite, The World Social Forum: Strategies of Resistance (Chicago: Haymarket Books, 2005). 
international law. The emerging jurisprudence of social justice and human rights in these countries, and indeed others, ${ }^{3}$ is critical to these inquiries.

\title{
II. HUMAN RIGHTS MOVEMENTS IN KENYA
}

Human rights organizations have grown by leaps and bounds in Kenya since the end of the Cold

War. This is also true of many countries in Africa and elsewhere. ${ }^{4}$ These organizations struggle

\begin{abstract}
3. Malcolm Langford, ed, Social Rights Jurisprudence: Emerging Trends in International and Comparative Law (Cambridge: Cambridge University Press, 2008); Almut Schillig-Vacaflor, "Bolivia's New Constitution: Towards Participatory Democracy and Political Pluralism," (2011) 90 European Review of Latin America and Caribbean at 3-22; Rodrigo Uprimny, "The Recent Transformation of Constitutional Law in Latin America: Trends and Challenges," in (2011) 89 Texas Law Review 1587; Jonas Wolff, "The New Constitutions and the Transformation of Democracy in Bolivia and Ecuador," in Detlef Nolte/Almut Schillig-Vocaflor, eds, Constitutionalism in Latin America: Promises and Practice (Farham: Ashgate, 2012) 183-202; Roberto Gargarella, Latin American Constitutionalism, 1810-2010: The Engine Room of the Constitution (Oxford: Oxford University Press, 2013).

4. Makau Mutua, ed, Human Rights NGOs in East Africa: Political and Normative Tensions (Philadelphia: University of Pennsylvania Press, 2009); Makau Mutua, Kenya's Quest for Democracy: Taming Leviathan (Bolder: Lynne Rienner Publishers Inc. 2008); Murunga, Okello \& Sjogreen, eds, Kenya: The Struggle for a New Constitutional Order (London: Zed Books, 2014); Sarah J Ruto, Patricia Kameri-Mbote, Jacinta Muteshi-Strachan, Promises and Realities: Taking Stock of the $3^{\text {rd }}$ UN International Women's Conference (Nairobi: AWCFS \& ACTS Press, 2009); Yash P Ghai \& Jill Cottrell Ghai, Kenya's Constitution: An Instrument for Change (Nairobi: Katiba Institute, 2011); Makau Mutua, Human Rights: A Political and Cultural Critique (Philadelphia: Pennsylvania University Press, 2002); Yash Ghai \& Jill Cottrell, eds, Economic, Social and Cultural Rights in Practice : The Role of Judges in Implementing Economic, Social and Cultural Rights (London: INTERIGHTS, 2004); Yash Ghai \& Jill Cottrell, The Millennium Declaration, Rights, and Constitutions (New Delhi: Oxford University Press, 2011); Mahmood Mamdani, ed, Beyond Rights Talk and Culture_Talk (New York: St. Martin's Press, 2000); Willy Mutunga \& Alamin Mazrui, "Rights Integration in an Institutional Context: The Experience of Kenya Human Rights Commission," (2002) 8 Buffalo Human Rights Law Review 123; J. Oloka Onyango, "Beyond the Rhetoric: Reinvigorating the Struggle for Economic and Social Rights in Africa" (1995) 26:2 California Western International Law Journal; J. Oloka-Onyango and Sylvia Tamale, “"The Personal is Political," or Why Women's Rights are indeed Human Rights: An African Perspective on International Feminism" (1995) 17:4 Human Rights Quarterly 691; J. Oloka-Onyango, "Economic and Social Human Rights, the Universal Declaration and the New Millennium: What Prospects for Change?" (1998-99) 12:1 Interights Bulletin; J. Oloka-Onyango, "Human Rights and Sustainable Development in Contemporary Africa: A New Dawn or Retreating Horizons?"(2000) 6 Buffalo Human Rights Law Review 39; J. Oloka-Onyango, "Public Interest Litigation (PIL) and Human Rights in East Africa: A Bird's Eye View" (2015) 47:3 George Washington International Law Review ; J. Oloka-Onyango, "Debating Love, Human Rights and Identity Politics in East Africa: The Case of Uganda and Kenya" (2015) 14:2 African Human Rights Journal [Forthcoming]; J. Oloka-Onyango, "Modern-day Missionaries or Misguided Miscreants? NGOs, the Women's Movement and the Promotion of Human Rights in Africa", in W. Benedek, E.Kisaakye \& G. Oberleitner eds, The Human Rights of Women: International Instruments and African Experiences (London/New York: , Zed Books, 2002); J. Oloka-Onyango, Battling for Human Rights: Twenty Essays on Law, Politics and Governance (Bamenda: Langaa Publishing) [Forthcoming 2016]; Willy Mutunga, Constitution -Making from the Middle: Civil Society and Transition Politics in Kenya, 1992-1997 (Nairobi/Harare: Sareat/Mwengo, 1999); Willy Mutunga, "Feminist Masculinity: Advocacy for Gender Equality and Equity" in Makau Mutua, ed, Human Rights NGOs in East Africa: Political and Normative Tensions (Philadelphia: University of Pennsylvania Press, 2009) ch 5; Samuel Moyn, The Last Utopia: Human Rights in History (The Belknap Press of Harvard University Press, 2010), reviewed
\end{abstract}


for the rights of the youth, women, persons with disabilities, children, the aged, minorities, pastoralists, hawkers, peasants, workers, artisans, artists, writers, students, intellectuals, refugees, internally displaced persons, and many other groups. Some civil society groups challenge the violations of the rights of Kenyans by multinationals in the areas of environment, poverty, exploitation, debt relief, reparations, trade, indigenous knowledge, investments and repatriation of profits. ${ }^{5}$ Yet others have continued to agitate for the promotion and protection of economic, social, and cultural rights of Kenyan citizens. ${ }^{6}$ These concerns that address the whole gamut of human rights for lives and livelihoods are not idle concerns. They reflect the deep commitment of very many Kenyans to the country's self-determination and independence. And there is, in fact, a consolidated human rights movement in Kenya. ${ }^{7}$

In part, this movement owes its emergence to Kenyan intellectuals who have written tirelessly and critically on the human rights discourse. ${ }^{8}$ But the human rights movement is also attributable to reformers and activists who work in human rights groups at the community,

by Willy Mutunga in (2012) 30:4 NHJR 515-520; Issa Shivji, The Concept of Human Rights in Africa (London \& Dakar: Codesria, 1989).

5. Mutunga, Gesualdi and Ouma, Exposing the Soft Belly of the Multinational Beast: The Struggle for Workers Rights at Del Monte_Kenya (Nairobi: KHRC, 2002). As Arudhati Roy has observed on page 3 of a speech given at the Opening Plenary of the World Social Forum in Mumbai, on January 16, 2004 entitled Do turkeys enjoy thanksgiving? "A government's victims are not only those it kills and imprisons. Those who are displaced and dispossessed and sentenced to a lifetime of starvation and deprivation must count among them too. Millions of people have been disposed by 'development' projects. In the past 55 years, Big Dams alone have displaced between 33 million and 55 million people in India. They have no recourse to justice." On the same page she adds, "In the era of corporate globalization, poverty is a crime."

${ }^{6}$. Kenya Human Rights Commission and Haki Jamii are the leaders in this field.

7. "A movement is a complex phenomenon, it is dynamic, and it grows and grows as more and more people join the 'project' (if it makes sense to them, and involves them in its deepening and broadening). A movement is like small rivers joining to form a massive torrent." Yash Tandon, ANSLA (Alternatives to Neo-Liberalism in Southern Africa) strategy task force, Southern Africa, June 2004, (mimeo.) at 37. “...there is no Chinese (Israel) wall between 'elite' and 'popular' movements. The self-organization of different groups makes social movements a contradictory phenomenon. To not recognize this and equate social movements with popular movements would be to let one's programmatic aspirations overwhelm the analytical agenda." Mahmood Mamdani, "Introduction," in Mahmood Mamdani \& Earnest Wamba-dia-Wamba, eds, African Studies in Social Movements and Democracy (Dakar: CODESRIA, 1995) 1 at 7.

${ }^{8}$. See note 4. 
HUMAN RIGHTS STATES AND SOCIETIES

national, and regional levels. The bulk of the youth and women ${ }^{9}$ have emerged as soldiers of this movement, as have trade unionists ${ }^{10}$ and small farmers ${ }^{11}$ who have invoked human rights discourse in their struggles for better working conditions and fair commodity prices. There is no doubt very many Kenyans are resisting human rights violations. ${ }^{12}$

Even so, there is a clear need to interrogate what the movement is fighting for, the challenges posed to that movement, its gender make-up, the limitations of the human rights discourse, ${ }^{13}$ the networks that have to be formed, and the movement's caliber and quality, especially in relation to its leadership. But the pessimism and optimism of what lies ahead needs elucidation, substantiation, and legitimation. There must be an intellectual, ideological, and political vision of the human rights project in Kenya. This vision must go beyond the realization of a human rights state in Kenya. This much is clear -- there will be no human rights state in Kenya unless the movement captures political power in the country. Such a state will thereafter be ruled by leaders committed to the protection and promotion of human rights and who are capable of leading Kenya towards a post-human rights state. This alternative political leadership in Kenya must be comprised of other social movements to rescue it from the limitations of the human rights leadership. This alternative political leadership already exists in Kenya. What it lacks at the moment is a critical constituency and a political party. The challenge of an alternative political leadership is part of the deepening political crisis in the country.

\footnotetext{
${ }^{9}$. See Muteshi et al, supra note 4.

10. Mutunga, Gesualdi and Ouma, Exposing the Soft Belly of the Multinational Beast, supra note 5.

${ }^{11}$. Ruteere, Dying to be Free: The Struggle for Rights in Mwea (Nairobi: KHRC, 2000).

12. Yet we cannot say that the consolidated human rights movement has a critical mass following within the country. This is a fundamental challenge to the movement if it will ever capture political power. It is arguable that even the middle class following that the movement has needs consolidation as it is torn by the usual divisions based on ethnicity, race, gender, generation, religion, region, occupation and clan.

13. “... a human rights approach on its own will not be effective; there are powerful vested interests and certain power configurations at national and global levels that need to be challenged in order to bring about necessary change." Yash Tandon, supra note 7 at 5. Undoubtedly the human rights approach can expose and demystify these vested interests and power configurations and provide some advocacy tools of challenge. Advocacy and activism have their limitations in the challenging the vested interests and power configurations.
} 


\section{THE CONCEPTUALIZATION OF HUMAN RIGHTS}

This author and Alamin Mazrui have addressed the issue of the conceptualization of human rights elsewhere. ${ }^{14}$ In that piece, we argued that the human rights corpus reflects diverse conceptions of liberal democracy and pointed to the Euro-centeredness of the corpus in its origin and general orientation. We also noted that some conceptions such as the right to selfdetermination have had a revolutionary and transformative character when invoked and implemented in struggles for independence. We contended that the human rights corpus has been used in the countries of the Global South to struggle against their political dictatorship. We argued that the corpus reflects a quasi-legalistic orientation where the focus implicitly or explicitly is on remedies that amount to little more than a better domestic implementation of universal human rights instruments. We agreed with Shivji that "human rights talk constitutes one of the main elements in the ideological armory of imperialism," ${ }^{15}$ but we also noted that human rights discourse can be an ideology of resistance. ${ }^{16}$ We highlighted the legacy of the Cold War and its impact on the human rights discourse. The Cold War's legacy's watershed is the Vienna Declaration of 1993 that affirmed the interdependence of various basic rights, indeed, the whole gamut of human rights. ${ }^{17}$ We warned that human rights does mitigate market

\footnotetext{
14. "Rights Integration in an Institutional Context: The Experience of Kenya Human Rights Commission" (2002) 8 Buffalo Human Rights Law Review 123 at 128-132.

${ }^{15}$.Issa Shivji, The Concept of Human Rights in Africa (Dakar: Codesria, 1989), 5.

16. Issa Shivji argues that if not properly handled human rights may not serve as an ideology of resistance. Human rights discourse could be a discourse of exposure and demystification of oppression and nothing else. See Issa Shivji, "The Life and Times of Babu: The Age of Liberation and Revolution" Keynote Address delivered at the International Conference to celebrate the life of Comrade Abdulrahman Babu, September 21-22, 2001 University of Dar es Salaam (mimeo.)

17. 'It is customary to categorise human rights at three levels - the political or civil rights (or 'blue rights'), economic rights (or 'red rights'), and social and cultural rights (or 'green rights'). There is much discussion on the relative importance of these values, for example, whether democratic rights take precedence over economic rights, or whether democratic rights need to be put in abeyance until people have enough to eat and enjoy basic economic well being. These are false debates, or at best academic debates delinked from the real world. All rights must viewed holistically, as interdependent whole. There is a tendency in certain circles (for example in the Millennium
} 
HUMAN RIGHTS STATES AND SOCIETIES

fundamentalism, and is the only discourse to do so consistently after the fall of socialism and communism in 1989. We suggested that this is why the human rights discourse has a social democratic content. We emphasized that human rights discourse can dispute and attack the conceptions of property within the capitalist idiom and address issues of substantive justice that fundamentally affect the way wealth and other resources are redistributed. We reminded human rights conceptualizers and activists that the human rights discourse does reflect in part the great paradigms that not only exposed and demystified market fundamentalism, but also provided a road map for the total subversion of market fundamentalism.

\section{CONCEPTUALIZING THE STATE}

Various analyses give characteristics, features or ingredients that are a shell for depicting a conventional conceptual framework of the state. ${ }^{18}$ These features include the jurisdiction of the

Development Goals - MDGs) to isolate economic rights - among them, access to basic necessities of life such as health, education, water, shelter, clothing and housing - as the 'targets' to achieve by a certain date in the future (in the case of the MDG, by 2015). These rights are, of course, very important, but their deficit in the contemporary world cannot be understood in isolation of the underlying causes (national and global) that create poverty and deprivation at the national and global levels". Supra note 7 at 5; See also what Yash Tandon had to say about the universality of human rights:

"It [universality of human rights] is the only measure we have for questioning derogation of state and imperial behaviour from principles of humanity. And it is the only reed the poor and the vulnerable have from being otherwise totally drowned. Yash Tandon, "Humanolgy and Human Rights: The Challenge of Global Trading System" paper read in a conference on Human Rights in East Africa, Emergent Themes, Challenges and Tensions, October 9-10, 2004 at 14 (mimeo.); In giving a solution to the crisis of the post-colonial nation-state project Adebayo Olukoshi and Liisa Laakso, supra note 25 at 33,argue that: The need to promote social equity, a minimum standard for human welfare, a viable economy, and a clear charter of citizen's rights which aims to promote civil liberties and human rights, political and electoral pluralism, and effective public institutions (especially in the areas of education, health, and the administration of justice) ought to be more fully recognized as urgent and brought closer to the centre stage of national political and policy discourses. These are issues which are too crucial to be left to a small, largely unrepresentative political elite, foreign agencies/donors, or market forces. A relatively strong and democratic state apparatus is necessary in Africa, if the current social crisis is to be tackled. Some of the features of "a relatively strong and democratic state" are reflected in a human rights state. See also Yash Ghai, Social Development: Towards Democratization and Social Justice (Geneva: UNRISD, 2001).

18. I have found Andrew Vincent, The Theories of the State (Oxford: Blackwell, 1987) 1-44, a useful source in this endeavour. Mahmood Mamdani gives a succinct clarification of the state as follows: "The state is more than a government. It comprises all the instruments which are set up to enable a particular class to rule and includes the forces of repression (the army, the police, and intelligence), regulation (the courts) and administration (the civil service). Even in a bourgeois democracy, the elective principle is confined to the sphere of government. All other instruments of the state remain non-elective. These instruments are the real embodiment of class rule. Positions in 
state regarding identifiable boundaries and territory; a population or citizenry living within the territory; the control of the machinery of violence invariably called the instruments of law and order; control of the resources within the territory; the legal supremacy of the state over other groupings within the territory based on constitutions or other legal instruments; a history of the state; and the principle of sovereignty that gives the state an autonomy and legitimacy in the community of regional, continental, and international states. The essence of state features is ideological and political. So the state has been called the "collective capitalist," "the executive committee to manage the affairs of the bourgeoisie," a tool of the ruling classes or elites, ${ }^{19}$ the sole definer of political space ${ }^{20}$; an institution that regulates class conflicts and embodies the diversity of society, a site of political struggles, "a complex of ideas and values, some of which have an institutional reality," 21 and "a continuous public power.",22

The complexity of ideas that make up the state is part of the essence of the state but is also a tool to critique the shell of the state. For example, the feature of sovereignty, once confronted by the reality of external forces such as the engines of globalization, ${ }^{23}$ cannot possibly be analyzed in a vacuum. It has to be done within the reality of globalization and the so-

this sector are filled in by direct appointment. This is why parliamentary democracy is just one form of bourgeois rule." Mahmood Mamdani, Imperialism and Fascism in Uganda (Nairobi: Heinemann, 1983) 42.

${ }^{19}$. The current US state in my view reflects these three categorizations perfectly. Just take the example that is well known of research that takes place in the military and universities, financed by the taxpayer, whose final products are handed over to the private sector for free. The private sector products end up being purchased by the state itself among other buyers. It is an example you will find repeated in quite a number of Noam Chomsky's works. For the most recent exposition of this, see, (2004) 37 International Socialist Review 19-20. "And that's how the economy works. The core of it is the state sector," at 19.

${ }^{20}$. Antony Jarvis \& Albert Paolini, "Locating the State," in Joseph Camilleri, Antony Jarvis \& Albert Paolini, eds, The State in Transition: Reimagining Political Space (London: Lynne Rienner Publishers, 1995) 3 at 4; See for origins of modern state, Poggi Gianfranco, The State: Its Nature, Development and Prospects (Cambridge: Polity Press 1990).

21. Supra note 13 at 6.

${ }^{22}$. Ibid at 21.

23. Jerry Mander \& Edward Goldsmith, eds, The Case Against the Global Economy (San Francisco: Sierra Club Books, 1996); Joseph Stieglitz, Globalization and its Discontents, infra note 18; Sidney Lens, The Forging of the American Empire: From the Revolution to Vietnam: A History of American Imperialism (New York :Crowell, 1974). 
HUMAN RIGHTS STATES AND SOCIETIES

called new world order. ${ }^{24}$ The population of a given territory is not homogeneous. The population reflects the diversities of class, ethnicity, religion, gender, generation, region, clans, languages, history, occupation, and race. ${ }^{25}$ Nor are the boundaries of a given territory free from critique when the history of their demarcations taken into account or when their impact on autonomous developments of various regions is discussed. ${ }^{26}$

This background is foundational to the conceptualization of a human rights state. Therefore, the various features outlined depicting the state reflect ideas that analyze the shell and the essence of the state. ${ }^{27}$

\section{CONCEPTUALIZING A HUMAN RIGHTS STATE}

\section{A. BACKGROUND}

The categorization of 'a human rights state' is recent and unique. The first time I read of the concept or notion of a human rights state was in Makau Mutua's 1997 article. ${ }^{28}$ I was captivated

\footnotetext{
${ }^{24}$. For East Africans our intellectuals have written on this issue: D.W. Nabudere, The Political Economy of Imperialism (London: Zed Press, 1977); D.W. Nabudere, Imperialism in East Africa: Imperialism and Exploitation (Africa Series) (London: Zed Press, 1981); D.W. Nabudere, Imperialism in East Africa: Imperialism and Integration (London: Zed Press,1982); D.W. Nabudere, Imperialism and Revolution in Uganda (London: Onyx Express, 1980); Issa Shivji, Class Struggles in Tanzania (Dar es Salaam: TPH, 1976); Mahmood Mamdani, Class Formations in Uganda (Princeton: Princeton University Press, 1975); Mahmood Mamdani, Imperialism and Fascism in Uganda(Nairobi: Heinemann, 1983); Yash Tandon, ed, The Dar es Salaam Debate on Class, State and Imperialism (Dar es Salaam, TPH, 1982); L. Khamis, Imperialism Today (Dar es Salaam: TPH, 1983); Anonymous, Independent Kenya (London: Zed Press, 1982). Two friends of East Africans are worth reading: Walter Rodney, How Europe Underdeveloped Africa (Dar es Salaam: TPH, 1972); Samir Amir, "Eurocentrism" (New York: Monthly Review, 1989). For intellectuals who support globalization but want an alternative form, a form that mitigates globalization and market fundamentalism see, Joseph Stieglitz, Globalization and Its Discontents (London: Penguin, 2002); Amartya Sen, Development as Freedom (New York: Anchor Books 1999) and Peter Singer, One World: The Ethics of Globalization (New Haven: Yale University Press, 2002).

25. Laakso and A. Olukoshi, "The Crisis of the Post-Colonial Nation - State Project in Africa," in A. Olukoshi \& L. Laakso, eds, Challenges to the Nation - State in Africa (Uppsala, Nordic African Institute, 1996) 7.

${ }^{26}$. Basil Davidson, The Black Man's Burden: The Curse of the Nation-State (Nairobi: East African Educational Publishers, 1993) 99-117.

27. The following ideological and political categorizations of state are familiar: slave, feudal, bourgeois, socialist, communist, communal, colonial, neo-colonial, developmental, Marxist-Leninist, patrimonial, predatory, liberal, social-democratic, neo-liberal, multi-racial, multi-ethnic, imperial/imperialist, federal, omnipotent, failed, fragile, lame, authentic, struggling, rogue, puppet, client, gate-keeper, squatter, free market, ethical, people's, terrorist and welfare. For a mention of most of these categorizations in one volume see, Howell, Jude and Pearce, Jenny, Civil Society \& Development: A Critical Exploration (Boulder \& London: Lynne Rienner Publishers, 2001).
} 
by the analysis of the limits of the human rights discourse in new South Africa and forgot to pursue the concept of a human rights state raised in the article. In November 2001, I attended a seminar organized by Mahmood Mamdani at Columbia University on the political uses of the human rights discourse. One of the foci of the meeting was the limitations of the human rights discourse. We did not theorize or conceptualize the category of a human rights state. ${ }^{29}$ It was only when I joined the Ford Foundation in 2004 and the question arose regarding the foundational basis of human rights in all portfolios of the Foundation at its Eastern Africa Office ${ }^{30}$ and in particular the notion of Rights and Democracy in programming, ${ }^{31}$ that I revisited Mutua's article. I quickly saw the need to delve deeper into the concept of a human rights state and to take Mutua's analysis further. The purpose of this analysis, the conceptualization and problematization of a human rights state is simply to contribute further to the analysis on the limitations of human rights discourse and its ideological, intellectual, and political consequences in democratization transformation.

\section{B. WHAT IS A HUMAN RIGHTS STATE?}

Mutua begins his analysis of a human rights state by distinguishing "between a state that formally respects human rights, as do most political democracies, and a human rights state." ${ }^{32} \mathrm{He}$ proceeds to clarify the dichotomy by arguing:

\footnotetext{
28. "Hope and Despair for a New South Africa: The Limits of Rights Discourse" (1997) 10 Harvard Human Rights Journal 63. Jarvis and Paolini make a great point about conceptualization of states. "Thus, to question the relevance of the state, or to reimagine its space, or to suggest alternatives, is to inquire into our very relationship with ourselves and the society we live in." supra note 20 at 4-5.

29. The reviews of Mutua's book, Human Rights: A Political and Cultural Critique (University of Pennsylvania Press, 2002) to my knowledge have not problematized the concept of a human rights state. See, for example, the review by Henry J. Richardson in (2004) 52 Buffalo L. Review 511.

30. The five portfolios are Human Rights and Social Justice, Governance and Civil Society, Education and Sexuality, Environment and Development and Media, Arts and Culture.

31. The merging of programming of Human Rights and Social Justice and Governance and Civil Society both portfolios falling under Peace and Social Justice Program of the Ford Foundation.

32. Supra note 28 at 70 .
} 
HUMAN RIGHTS STATES AND SOCIETIES

To date, South Africa has had the best opportunity to create such a [human rights] state. Other states, such as Western democracies where the idea of individual rights was first born under liberalism, were not initially created as human rights states although they now embody many human rights norms in their constitutional and legal frameworks. A human rights state would not simply constitutionally guarantee civil and political rights while relegating economic and social rights to the precarious welfare state. Instead, in a true human rights state, all rights would be made constitutionally effective and practically realizable and enforceable. ${ }^{33}$

Still elaborating on the dichotomy, he states:

A human rights state, by contrast, is a term coined here to describe an aspiration - an ideal state that would be constructed from close adherence to the prescriptions of the human rights corpus. Although a human rights state is theoretically possible given the framework of human rights law, it remains a fiction at present, not having been accomplished anywhere. ${ }^{34}$

According to this analysis, South Africa fails the test of a human rights state mainly because human rights discourse is used to consolidate the relations of production formed or at least concretized under the apartheid state. What human rights discourse does in the case of South Africa is merely to generally and significantly de-racialize the apartheid state leaving the core of its ingredients intact. But the deracialization in post-Apartheid South Africa is formal, not substantive. The country is sharply divided into two nations - one First World and white, the other Third World and black. Similar parallels can be drawn both between South Africa on the one hand and Kenya and Zimbabwe on the other as settler states, and, indeed, between South Africa and the rest of independent Africa. ${ }^{35}$

\footnotetext{
33. Ibid.

34. Ibid at 71 .

${ }^{35}$.The Bill of Rights in the Constitutions of Kenya and Zimbabwe consolidated the rights of departing colonial power and its agents. The best example of this consolidation is the critical issue of land. The new constitutions validated what was clearly a monumental theft of the land of Africans by the imperial state of Britain and its agents, the white settlers. This issue is now agitated through mass occupations of land in Zimbabwe and transitional justice issues in Kenya where reparations for colonialism and neo-colonialism are constantly on the agenda. The Mau Mau veterans in Kenya are also demanding reparations for forced labour and torture during the British rule in Kenya. The veterans won their case filed in the UK. The British government has accepted and apologized for the atrocities perpetrated against the Mau Mau Freedom fighters. Some compensation, however, insufficient has been paid and a Mau Mau monument is being erected at the Freedom Corner, Nairobi City, all expenses paid by the British government. The monument will be unveiled in May 2015.
} 
Mutua's conceptualization is that a human rights state will enforce and realize the whole gamut of rights: political, civil, economic, social and cultural rights. The basis of this enforcement is pegged to "constitutionally effective" norms that the courts, the state, and the citizenry themselves make "practically realizable and enforceable." His conceptualization of a human rights state is, therefore, pegged to a framework of human rights law. Mutua also states that a human rights state is an ideal, an aspiration and a fiction because its accomplishment is yet to be achieved anywhere. However, Mutua does conclusively advocate for the struggle of a human rights state after carefully analyzing the political and legal pitfalls that hinder the realization of such a state, and does not call for, even by implication, the abolition of the human rights discourse. ${ }^{36}$

\section{CONCEIVING A HUMAN RIGHTS STATE}

There is no reason why a human rights state would not reflect the features of the "shell state" and the essence of a conventional state as underlined here. A human rights state is fundamentally a liberal democratic state that possesses the ingredients of radical social democracy. A human rights state retains the liberal democratic state's original revolutionary and transformative character $^{37}$ and, therefore, has the seeds of an ideology of resistance. It reflects the legacy of the Cold War era, and it is not as Mahmood Mamdani argues, "an imperialist Trojan Horse... but a contested terrain." 38 A human rights state emphasizes the narrow legal framework of human rights law and calls for reform within market fundamentalism that it seeks to mitigate. A human rights state reflects the unity of opposites: it can be used to agitate for social transformation for a more just and different world, but it can also be used as the basis for a world full of human rights

\footnotetext{
${ }^{36}$. Henry J. Richardson, supra note 29 seems to suggest this.

${ }^{37}$.To enforce and realize the whole gamut of human rights in any country the world over requires a transformative and revolutionary state!

38. Social Movements and Constitutionalism in the African Context, CBR working paper, NO. 2 (1989) 6.
} 
HUMAN RIGHTS STATES AND SOCIETIES

violations. So, the fundamental and consummate question is who controls that human rights state $?^{39}$

South Africa and the history of the ANC offer sobering thoughts for Kenyan progressives, radicals and reformers who are yet to capture political power. The revolutionaries, progressives, radicals, reformers and activists in the ANC were unable to realize South Africa as the first human rights state in Africa or anywhere else. Some of the reasons for this defeat are given in Mutua's article ${ }^{40}$ where he eloquently analyses the rhetoric behind land reforms, the reforms in the machinery of violence, and economic reforms among others. To talk of the human rights state in Kenya, therefore, is to talk of the right to transform the country and ultimately of the right to revolution if that remains on the political agenda. Kenyans have been talking about the right to revolution for over a century now. What is recent is the conceptualization and problematization of the human rights discourse as an ideology of resistance. This ideology of resistance will go beyond "exposure" and "demystification" of the root causes of human rights violations. Thus the ideology of resistance will concretely address solutions that result in fundamental social transformation in Kenya. And that may ultimately be the basis of the right of revolution in the country. In sum, it will entail a negation of rights in order to ensure their assertion. With the 'right to revolution' written into the script of governance in Kenya, I believe that we will be well on our way to a human rights state.

\footnotetext{
${ }^{39}$.This question will take us back to discussions on classes. Is the vision of the class that controls the human rights state that of mitigating market fundamentalism? Or is it a class that knows that such mitigation is but a milestone in the road map to full self-determination and independence? Is it a class that rejects the assumption that there is no other better system other than capitalist fundamentalism? Is it a class that is ready to learn the reversal lessons in Soviet Union, Eastern Europe, Albania, China, Cuba, Venezuela and even the African states that struggled for socialism? Is it a class that shuns dogma and is able to embrace the space that allows intellectual, ideological and political engagement with different liberationist paradigms since 1989? It is intellectual and ideological laziness to simply think that these questions are irrelevant if engaged in struggles for human rights states in East Africa.

40. Makau Mutua, supra note 28.
} 
For Kenya, therefore, the struggle for the development of a human rights state has the following key transformative ingredients:

- The reform of the human rights law framework is positive, and can create democratic space for resisting dictatorship.

- In mitigating market fundamentalism, human rights discourse provides an alternative development paradigm. ${ }^{41}$

- In challenging market fundamentalism, human rights discourse puts back on the agenda critical thinking on an alternative system to globalization and markets.

- Human rights discourse gives ideological and political space for the critical resurrection of the non-hegemonic and inclusive paradigms that imperialist propaganda has denounced as unworkable and dead. ${ }^{42}$

- The reform agenda based on this struggle for human rights states is qualitatively better than an agenda for the struggle for regime change that does not address fundamental problems.

- The clarion call for human rights states is a positive and progressive struggle for political power in a world that is agitating for alternatives to globalization and for a world based on global justice.

- The struggle for human rights states brings into sharp focus the question of alternative political leadership to control such a state.

\footnotetext{
${ }^{41}$. Yash Tandon, Towards An Alternative Development Paradigm, www.seatini.org

42. There has never been any doubt that the most fundamental criticism and analysis of market or capitalist fundamentalism have come from the Marxist paradigm as developed over years by its followers. While the political prescriptions and the experiences in various countries have brought into focus critical discussions on the viability of such prescriptions, the exposure and demystification of capitalist fundamentalism by that paradigm has never been the subject of dispute.
} 
HUMAN RIGHTS STATES AND SOCIETIES

- The connections among human rights, governance, democracy, and civil society are easily be discernable in the struggle for human rights states. ${ }^{43}$

- The struggle for human rights states emphasizes the limitations of human rights discourses that must be addressed for the struggle to be part of the larger struggle for social transformation.

\section{THE 2010 CONSTITUTION: THE CREATION OF A HUMAN RIGHTS STATE}

This section and the ones that follow attempt to establish the link between (on the one hand) human rights and the state as conceptualized above, and (on the other hand) the 2010 Constitution of Kenya and the judicial reforms and procedures under the Constitution. The reconstruction of the state and its decentralization and democratization is a key feature of this Constitution. Unlike any other Constitution in the world the Kenyan one places fundamental emphasis on national values and principles that both impact power and how politics is organized. We take the Judiciary as a pivotal institution under the Constitution that must promote and protect the human rights state and society. Its role in the implementation of the Constitution is of cardinal importance. Establishing such a link as attempted here serves to illuminate the importance of human rights.

\footnotetext{
43. The examples are legion. Take for example, the struggle for a new constitution. This struggle is for the construction of a new state that is opposed to authoritarianism. It is a program for reform and its ultimate provisions provide for governance, democracy and human rights. This example is discussed in detail when the vision of the 2010 Constitution of Kenya is analyzed.
} 


\section{A.THE VISION OF THE CONSTITUTION OF KENYA ${ }^{44}$}

\section{a. Background}

The making of the Kenyan 2010 Constitution is a story of ordinary citizens striving and succeeding to reject and overthrow the existing social order as a precursor for a new social, economic, cultural, and political reality. Some have spoken of the new Constitution as representing a second independence. There is no doubt that, with respect to its values and practices, this Constitution is a radical document that looks to a future very different from the past. It seeks to make a fundamental break with 68 years of colonialism and 50 years of independence.

\section{b. The Constitution: Objective and Purpose ${ }^{45}$}

In 2010, the Kenyan people decreed that the status quo was unacceptable and unsustainable. They resolved to reconstitute and reconfigure the Kenyan state from its former vertical, imperial, authoritative, and unaccountable ogre to an accountable, horizontal, decentralized, democratized, and responsive state. Under the new Constitution, the vision of nationhood would be premised on core norms, including the following: national unity, political integration and diversity; democratization and decentralization of the Executive; devolution; public service; popular sovereignty in which the state is a servant, not master; integrity in public leadership; a Bill of Rights that provides for economic, social and cultural rights to reinforce political and civil rights

\footnotetext{
${ }^{44}$. This aspect of the paper is taken from the Inaugural Distinguished Lecture I gave at the University of Fort Hare, South Africa on October 14, 2014 entitled: "The 2010 Constitution of Kenya and its Interpretation: Reflections from Supreme Court Decisions." Albie Sachs has reflected at length and brilliantly on this issue of interpreting the South African Constitution in his speech at a conference held in Nairobi on June 14-15 under the theme of interpreting and shaping a transformative constitution. As he noted: "All of us accepted that the Constitution is a public document that has to be interpreted with a public meaning, that it was deeply rooted in South African history of trauma and hope and that it needed to be implemented in a manner that was responsive to our country's socio-economic reality." 45. See Yash Pal Ghai, "Constitutions and Constitutionalism: The fate of the 2010 Constitution," in Godwin Murunga, Duncan Okello and Anders Sjorgren, eds, Kenya: The Struggle for a New Constitutional Order (London: Zed Books, 2014) 125-127. At 127 Yash Pal Ghai conceives this constitution as "a revolutionary constitution but no revolution." The discussion on objectives is one about the basic structure of the Constitution. In my opinion the ingredients of the basic structure of the 2010 Constitution of Kenya are broad and all encompassing reflecting the great commitment by Kenyans to fundamentally restructure the status quo of their society.
} 
HUMAN RIGHTS STATES AND SOCIETIES

(giving the whole gamut of human rights the power to radically mitigate the status quo and signal the creation of a human rights state and society in Kenya); mitigation of the status quo in the area of land tenure/control that has been the country's Achilles heel in its economic and democratic development; the strengthening of institutions; and the development of institutions that provide democratic checks and balances. The Kenyan people chose the route of transformation to end poverty and deprivation and regain dignity and sovereignty. Thus, to the extent that revolution was envisaged it was to be organized around the implementation of the Constitution. ${ }^{46}$

The 2010 Constitution reflects the vision of those patriots who struggled and fought against domination, exploitation, and oppression by British colonialism. History records similar invocations of discourses of reform, revolution, human rights, social justice, patriotism, freedom, nationhood, among others which are decreed in the 2010 Constitution. ${ }^{47}$

\section{B. FROM “BIG MEN" TO STRONG INSTITUTIONS}

The building of strong institutions must be basis for the transformation of Kenya. It is a necessity born out the history of the imperial presidency. The 2010 Constitution creates core institutions to defang the state and neuter the imperial presidency. Its norms and institutions are meant to prevent the resurrection of executive dictatorship. These include county governments, constitutional commissions, checks and balances, independence and principles inter-dependence

\footnotetext{
46. Samir Amin, "The World We Wish to See: Revolutionary Objectives in the Twenty-First Century" (New York, Monthly Review Press, 2008) 17: "The 'great revolutions' are distinguished by the fact that they project themselves far in front of the present, toward the future, in opposition to others (the 'ordinary revolutions') which are content to respond to the necessity for transformation that are on the agenda of the moment." Yash Pal Ghai supra note 43. I believe we also need to debate the viability of 'ordinary revolutions' as basis of the 'great' ones. Such debates have taken place in the past. See, for example, Helen Scott, ed, The Essential Rosa Luxemburg (Chicago: Haymarket Books, 2008) 41-104.

${ }^{47}$. Maina wa Kinyatti, History of Resistance in Kenya, 1884-2002 (New York: Mau Mau Research Centre, 2008).
} 
between state organs, and equitable distribution of national resources. ${ }^{48}$ Below I discuss the most important of these institutions, especially the Judiciary and its role in the implementation of the Constitution.

\section{DECOLONIZING JURISPRUDENCE IN THE NEW JUDICIARY}

Yash Ghai, the distinguished professor and constitutional law scholar, has argued that:

Perhaps realizing its own ambitious project, and hence its vulnerability and fragility, the Kenyan Constitution sets, through the judiciary, its barricades against destruction of its values and weakening of its institutions by forces external to itself. Such is the responsibility of Kenya's judiciary ${ }^{49}$

It is remarkable and a paradox that, although disappointment with the judiciary was at least as great among the common Kenyan as frustration with politicians, they chose to place their faith in the institution of the new judiciary in implementing the new Constitution. ${ }^{50}$ They did so by promulgating a Constitution that provides for the appointment of women and men of integrity by an independent and broadly representative Judicial Service Commission; ${ }^{51}$ providing for institutional and decisional independence of the Judiciary and the judicial officers respectively; ${ }^{52}$ through the vetting of judges and magistrates who served before August 27, 2010 by a body with broad criteria upon which to determine the suitability of these judicial officers; ${ }^{53}$ and by establishing the Judiciary Fund to provide financial independence of the Judiciary; ${ }^{54}$ and by setting up an apex court, the Supreme Court to be the final protector and custodian of the

\footnotetext{
48. Former President Moi's slogan of imperial presidency was in Kiswahili: Siasa Mbaya, Maisha Mbaya/Bad politics begets no livelihoods! And bad politics was any opposition to his leadership. Resources were denied to areas and communities that opposed his policies and leadership.

49. Unpublished mimeograph, Nairobi 2014.

${ }^{50}$. The High Court enjoys vast powers such as interpreting the Constitution which encompasses a power to determine whether "anything said to be done under the authority of this Constitution or any law is inconsistent with, or in contravention of" the Kenya Constitution 2010 (art 165) (3) (d) and to declare such conduct, omission, or law null and void to the extent of its inconsistency. Kenya Constitution 2010, art 2(4).

51. Ibid, art 171.

52. Ibid, art 160 .

53. Ibid, Section 23 of the Sixth Schedule of the Constitution.

${ }^{54}$. Ibid, art 173.
} 
HUMAN RIGHTS STATES AND SOCIETIES

supremacy of the Constitution. ${ }^{55}$ It also requires the vetting of existing judicial officers and the transparent recruitment of new judicial officers which includes public participation. The judiciary of Kenya must rise to the occasion and shake off the legacy of colonialism this will involve several approaches. ${ }^{56}$

The bedrock of this new dispensation must be instilling into Kenyans and judicial officials the centrality of impartiality and integrity in the new judiciary. The judiciary cannot be suspected of deferring to the executive ${ }^{57}$, or bending the law to suit favored clients or close associates. The idea of receiving, or soliciting a bribe should be unthinkable. Secondly, the position a judge should a hallowed one in the profession. The best lawyers should aspire to join the judiciary. Judges must be of the highest intellectual calibre, with a mastery of legal principles and techniques, an unimpeachable work ethic, and a commitment to fairness. Thirdly, Kenya must do away with archaic and opaque ceremonies, interminable procedures, and obfuscating language that make justice remote and unreachable to ordinary people. Unacceptably, Kenya has held to these totems of a bygone era even though they have largely been abandoned in Britain, their original home. While English Court procedures have over time been made simpler, some archaic terminology has been done away with, case management has been firmer, and ADR has become prevalent, Kenya still hears cases in driblets. These traditions are arcane and oftentimes mandate dictatorship. What are needed are radical changes in judicial policies, judicial culture, and end of judicial impunity and laziness. Fourthly, the Constitution gives the judiciary mandate to carry out reforms to root out colonial and neo-colonial inefficiencies and injustices. Fifthly,

\footnotetext{
55 . Ibid, art 163 .

56. See Willy Mutunga, “Kenya: A New Constitution,”(October 2013) 65 Socialist Lawyer 21.

57. The Executive is not the only force that threatens the independence of the Judiciary. Parliament's powers have been strengthened and also pose a threat. Forces from corporate, civil society, political parties, and legal and illegal cartels remain extremely powerful. Forces that divide Kenyans, namely ethnicity, region, religion, race, xenophobia, gender, generation, clan and class, and occupation are reflected in the Judiciary itself. Community, family, and friends are forces that cannot be underestimated.
} 
there is an URGENT need to develop new competent, indigenous jurisprudence. This last adjective is drawn from the Constitution's value of patriotism. It requires the judge to develop the law in a way that responds to the needs of the people, and to the national interest. This is a robust rich, patriotic, indigenous, and jurisprudence as decreed by the Constitution and the Supreme Court Act of Kenya. ${ }^{58}$ Above all, it requires a commitment to the Constitution and the achievement of its values and vision. ${ }^{59}$ Sixthly, it is a myth that judges in the Common Law system do not make law. ${ }^{60}$ The Constitution vacates that comforting illusion, especially in the context of human rights, when it provides under Article 20 (3) (a) that "a court shall develop the law to the extent that it does not give effect to a right or fundamental freedom". This means that if an existing rule of common law does not adequately comply with the Bill of Rights, the court has the obligation to develop that rule to make it compliant. It is matched in Article 20(3) (b) by an obligation to adopt the interpretation that most favors the enforcement of a right or fundamental freedom rather than diminishing, undermining, or subverting it. This is an obligation, not to rewrite a statute, but to read it in a way that is compliant with the Bill of Rights. The Bill of Rights and the Constitution should be used as the touchstone of legal appropriateness. ${ }^{61}$ The Constitution says no less. ${ }^{62}$

\section{A. A ROBUST, INDIGENOUS, PATRIOTIC, AND PROGRESSIVE JURISPRUDENCE}

The elements of a decolonizing jurisprudence discussed here, shun mechanical jurisprudence. The decolonizing jurisprudence of social justice is not insular or inward-looking. The values of

\footnotetext{
58. Supreme Court Act, 2011 No. 7 of 2011, s 3.

59 . See the Constitution of Kenya 2010: the Preamble, arts 2(4), 10, 20(3), 20(4), 22, 23, 24, 25,159, $191(5)$ and 259. These articles decree how the Constitution is to be interpreted and, indeed, under art 10(1) (b) any law, "any law" would include, in my view, rules of common law, as well as statute.

60. S.B. Sinha, "Creative interpretation of the Constitution: Role of the Supreme Court of India" (2004) Delhi Judicial Academy Journal 26.

${ }^{61}$. I have adverted to this In the Matter of the Principle of Gender Representation in the National Assembly and Senate, Supreme Court Application NO 2 of 2012 at Paras 8.1 and 8.2 of my Dissenting Opinion.

62. Kenya Constitution 2010, art 259 prescribes how the text of the Constitution is to be interpreted.
} 
HUMAN RIGHTS STATES AND SOCIETIES

the Kenyan Constitution are the exact opposite. Lessons should be drawn from other countries.

The concern here with an emphasis the "indigenous" is simply that Kenya's jurisprudence should be grown with local needs in mind, without unthinking deference to other jurisdictions and courts, however, distinguished. The quality of Kenyan progressive jurisprudence would still command respect in these distinguished jurisdictions. After all, Kenya's constitution is arguably one of the most progressive in the world. ${ }^{63}$ Of course, commonwealth and international jurisprudence will continue to be pivotal to the development of Kenya's jurisprudence. Yet, at the same time, the Judiciary will have to avoid mechanistic approaches to precedent. It should not cherry pick precedent from India, Australia, South Africa, the US, or from wherever on a whim just to suit the immediate purpose. Precedent has its place in the jurisprudence of each country. It is negative and mechanistic to approach precedent with a mind-set that says: "If we have not done it before, why should we do it now?" The Constitution does not countenance or encourage this approach. ${ }^{64}$ Kenyan jurisprudence must seek to reinforce those strengths in foreign jurisprudence that fit the country's needs ${ }^{65}$ while at the same time rescuing the weaknesses of such jurisprudence to enrich that which is decreed by the Supreme Court Act.

\footnotetext{
${ }^{63}$. Some of the key elements to this claim are: the most modern Bill of Rights in the World; uniquely provides for a theory of its interpretation; it reflects a social democratic transformation in a world still dominated by contemporary capitalism called neo-liberalism; and it calls for a progressive jurisprudence that shuns staunch positivism and its backwardness in a world that has to change. It has been argued that the claim to progressiveness is hindered by its failure to guarantee rights of LGBTIQ, abortion rights and the repeal of the death sentence. Looking at the grey areas in the constitutional provisions on these issues one can argue that the final verdict on this debate lies with the courts. Several recent cases illustrate that Kenyan courts have not shied away from turning these gray areas black and progressive. See Eric Gitari v Non-Governmental Organisations Coordination Board \& 4 Others [2015] eKLR; Republic v Kenya National Examinations Council \& Another Ex Parte Audrey Mbugua Ithibu [2014] eKLR; Baby 'A" (Suing through the Mother E A) \& Another v Attorney General \& 6 Others [2014] eKLR. It needs to be admitted that the Constitution protects private property under art 40 and simply mitigates relations of production in the country. See Roberto Gargarella, Latin American Constitutionalism 1810-2010: The Engine Room of the Constitution (Oxford: Oxford University Press, 2013) Ch 9. On providing fundamental changes to foreign domination of the economy and the protection of community lands the 2010 Constitution does not go as far as the Constitutions of Venezuela, Ecuador and Bolivia.

${ }^{64}$. As a guide to the emerging tests by which we should judge the relevance of foreign precedents an example is where we adopt foreign precedents but explain the parallels between that country and Kenya and its Constitution.

65. The criteria for determining our needs can be based on the discussion above on the values, vision, objectives and purpose of our Constitution.
} 


\section{B. THE NEW APPROACH}

The task of growing radical jurisprudence involves partnership between judiciaries, the legal profession, and scholars. The Bar must respond to the challenge. Standards of advocacy need to improve, the overall quality of written and oral submissions needs to be raised. The Jurisdictions of India, Namibia, Benin, South Africa and Colombia are great partners because of their similarity to Kenya's constitution. Decolonizing jurisprudence requires South-South collaboration and collective reflection.

The Kenyan judiciary is moving to limit excessively detailed written submissions. This makes sense only if the judges read the written submissions in advance. And they must do so with a critical eye, prepared to interrogate the arguments of counsel, and to put forward alternative ideas. It is a questionable practice to come up with ideas and authorities in the privacy of Judges' chambers when writing a judgment, if counsel had no chance to offer argument on those ideas and authorities. The very purpose of written submissions is to prevent such problems and to enable the judge to be well prepared in advance. A well-read judge is in a much stronger position to criticize counsel for lack of adequate of preparation. Through this dialogue, the Bench can encourage higher standards of advocacy. In the long run, this process should speed up the work of the court and clear backlog.

This task is being made easier by the enhancement of the quality and quantity of legal materials available to the bench through the legal researchers who have been appointed for all judges. It is a learning experience for the Kenyan Judiciary and its legal researchers to work out how the cause of justice can best be served by the innovation recently decreed by the Judicial 
HUMAN RIGHTS STATES AND SOCIETIES

Service Act, $2011 .{ }^{66}$ This offers the bar and the bench an opportunity to make major strides in the quality of the jurisprudence in the courts of Kenya.

These strides in the quality of jurisprudence in Kenyan courts can be amplified with the improvement of collegiality and co-education among judges and lawyers. This will make sure that decisions of the Kenyan courts reflect the collective intellect distilled through the common law method, regular discourses, learning, and exchange, by judicial officers. To be a good judge involves continuous training, learning, and regular informal discourses among judges without compromising the right of a judge to dissent. Dissents have their own purpose, but consensus building is equally important.

Kenya's Judiciary Training Institute (JTI) must become the judiciary's institution of higher learning, the nerve centre of our progressive jurisprudence. The old judiciary had all but killed this Institute. For, until recently, virtually all of its work had consisted of an annual colloquium where judges made merry and shunned intellectual reflection and engagement. The old Judiciary also reflected how hard it is for judges trained and brought up in the old style to make the adjustments that reforms require, and that it why programs of training and induction are so necessary. The JTI has now been revived ${ }^{67}$ and co-ordinates academic networks, networks with progressive jurisdictions, our training by scholars and judges, starting with Kenya's great scholars and judges. The training to breathe life into Kenya's constitution and jurisprudence has shunned legal-centric approaches by placing critical emphasis on multi-disciplinary approaches and expertise. JTI has brought equity into training for all, in competition for scholarships and travel, in creating a culture of glorifying excellence that did not exist. It is a critical centre for the development of Kenya's robust, indigenous, progressive, and patriotic jurisprudence. Through its

\footnotetext{
66. Judicial Service Act, No. 1 of 2011, s 7.

67. No wonder those who resist judicial transformation are now scrambling to control it. Too late, the train has left the train station and it cannot be derailed!
} 
coordination of transformation activities in the Judiciary it is now possible to know how many cases are in the system, the correct data on backlog, data to assess judicial performance, and making data the king of the reforms undertaken. ${ }^{68}$ Through coordination by JTI, financial and human resource manuals have been developed, bench memoranda, codes of ethics and conduct, anti-sexual harassment policy, transfer policy, among other polices are now available.

Law reporting is now regular under the able leadership of the National Council on Law Reporting. It has also established a program of research on the "lost jurisprudence" during the years when reporting was non-existent. There is no doubt that many gems and nuggets of progressive jurisprudence will emerge from this process. There is great hope that the community of scholars will respond to the challenge equally. The quality and quantity of Kenyan legal literature is disappointing. There is dire need for high quality commentary on the Constitution and ordinary laws. ${ }^{69}$ High quality commentary is needed on judgments. No one should be overly sensitive to criticism. No one learns without criticism.

Article 159(2) (e) of the 2010 Constitution provides that the courts must protect and promote the purposes and principles embedded in it. As Chief Justice, I initially set out to establish a framework for purposeful interpretation in two Supreme Court matters. ${ }^{70}$ In $T h e C C K$ Petition 14 as Consolidated with Petitions $14 A, 14 B$ and $14 C$ the Supreme Court ruled on 29 September 2014 on the theory of the interpretation of the 2010 Constitution. The judgment mainstreamed the theory of interpreting the Constitution by making it a decision of a full bench

\footnotetext{
68. I know that those who resist our transformation call it "transgression!" When you find incompetence, thievery, dysfunction, tomfoolery, a general remarkable ease with below average, you transgress it!

69. We welcome the publication of PLO Lumumba \& Luis Franceschi, eds, The Constitution of Kenya, 2010: An Introductory Commentary (Nairobi: Strathmore University Press, 2014).

${ }^{70}$.In the Matter of the Principle of Gender Representation in the National Assembly and the Senate Advisory Opinion of the Supreme Court (Reference No 2 of 2012; In the Matter of Jasbir Singh Rai and 3 Others $v$ Tarlochan Singh Rai and 4 others (Petition NO 4 of 2012).
} 
HUMAN RIGHTS STATES AND SOCIETIES

of the Supreme Court. The lower courts below are bound by this theory of interpreting the Constitution.

The Kenya Constitution is unusual in setting out a theory of interpretation. This theory shuns staunch positivism and accepts the fact that judges make law. It allows judges to invoke non-legal phenomena thereby making the judiciary "an institutional political actor. ${ }^{71}$ It is a merger of paradigms that problematize, interrogate, and historicize all different outlooks in the building of a radical democratic content that aims to be transformative of the state and society. ${ }^{72}$ It is a theory that values a multi-disciplinary approach to the implementation of the Constitution. It is neither insular nor inward looking, and seeks its place in global comparative jurisprudence, equality of participation, development, and influence. The Kenyan Parliament, in enacting the Supreme Court Act 2011, (Supreme Court Act) has in the provisions of Section 3 of that Act reinforced this aspect of constitutional pre-occupation in its theory of interpretation.

The Constitution took a bold step in providing that "The general rules of international law shall form part of the law of Kenya" and "Any treaty or convention ratified by Kenya shall form part of the law of Kenya under this Constitution". ${ }^{73}$ Thus Kenya seems to have become a monist rather than a dualist state in which domestic and international law are both given effect in the Constitution.

The full implications of these developments will unfold as the courts interpret the law. It is important to note that in the past Kenyan judges did not ignore international law. They often quoted the Bangalore Principles on Domestic Application of International Human Rights Norms,

\footnotetext{
71. Upendra Baxi, "Demosprudence versus Jurisprudence: The Indian Judicial Experience in the Context of Comparative Constitutional Studies," (2014) 14 Macquarie Law Journal 3 at 10. See Albie Sach’s speech, supra at note 44.

72. Willy Mutunga, "Relational Contract Theory outside National Jurisdictions, (1993) Doctor of Jurisprudence Thesis at Osgoode Law School, York University Chapters II and III.

73. Constitution of Kenya 2010, ss 2 (5) and (6).
} 
although not as binding law, but merely as a useful guide. ${ }^{74}$ Now, however, the courts have greater freedom. Many issues will have to be resolved. Indeed, the Kenyan courts now have a great opportunity to be both users, as well as producers, developers, and shapers, of international law.

The task at hand in the Kenyan context is rather easier than that faced by some court systems in jurisdictions struggling to establish the validity of their place in the constitutional scheme. The principle in Marbury $v$ Madison, that established the possibility of the judicial review of legislation, and that at the same time firmed up the key place of the courts in the upholding of the US Constitution, is enshrined in Kenya's Constitution in its Articles 23(3) (d) and 165(3) (d)). The 2010 Constitution constitutionalizes the kind of public interest litigation ${ }^{75}$ that was judicially created in India. ${ }^{76}$ Kenya's path has been smoothed: the judiciary need not strive to establish itself as guarantor of the supremacy of the Constitution, or of the rights of the downtrodden. ${ }^{77}$ This mandate is explicitly given to the judiciary by the Constitution. The appointment of judges is designed to give them independence from the executive and the legislature so that it can "force other institutions of governance to do what they are supposed to do". The judiciary will need the moral stature, the legal skills, and the courage to execute this mandate.

\footnotetext{
74. Bangalore Principles on Domestic Application of International Human Rights Norms, principles 7 and 8.

75 . Constitution of Kenya 2010, ss 22(2) and 258(2).

76. S. Muralidhar, "The Expectations and Challenges of Judicial Enforcement of Social Rights" in Malcom Langford ed, Social Rights Jurisprudence: Emerging Trends in Comparative Constitutional Law (Cambridge: Cambridge University Press, 2008) 108-109.

77. It is a pillar of the Judiciary Transformation that the courts in Kenya will truly be viewed as the courts for all Kenyans, and the salvation of the Kenyan oppressed and bewildered. This will happen when informal forums for the administration of justice are connected to the formal court systems under the supremacy of the Constitution. See the Socialist Lawyer, note 56 at page 23.
} 
HUMAN RIGHTS STATES AND SOCIETIES

Finally, Article 159 (2) of the Constitution has restored "traditional dispute resolution mechanisms" with constitutional limitations. ${ }^{78}$ Courts are not the only forums for the administration of justice in Kenya. Traditional dispute resolution mechanisms tend to keep themselves as free as possible from lawyers, 'their law,' and the 'law system of the capital.,79 The development of the "Without the Law" jurisprudence will be a critical nugget in Kenya's progressive jurisprudence. Since traditional dispute resolution mechanisms will be conducted in the many national languages of Kenyan communities the collective outcomes of such ventures must enrich progressive jurisprudence, breathe life into the implementation of the Constitution, and strengthen Kenya's diversity and democracy. This linguistic approach to traditional dispute resolution will help in the translations that have to be undertaken of the Constitution to enrich the languages of the community through new vocabulary borrowed from around the globe and reflected in the Constitution. Kiswahili, the national language, will be enriched for use in translating the Constitution to other national languages. These unique experiences and outcomes will have their own comparative niche in the world.

The transformative constitution, a new judiciary that is developing a progressive jurisprudence to implement the constitution, and a theory of interpreting the constitution that binds all courts, will combine to lay a firm foundation for the existence and consolidation of a human rights state in Kenya. Transforming one institution can be a beacon of a broader transformation, but the success of this broader goal will ultimately depend on the vision and posture of the political leadership in power. Without commitment by the ruling elites to the kind

\footnotetext{
78. Under Article 159(3) of the Constitution traditional dispute resolution mechanisms shall not be used in a way that (a) contravenes the Bill of Rights; (b) is repugnant to justice and morality or results to outcomes that are repugnant to justice and morality; or (c) is inconsistent with this Constitution or any written law.

79. Arthurs, H., Without the Law: Administrative Justice and Legal Pluralism in the Nineteenth-Century England (Toronto: University of Toronto Press, 1985) 10.Several passages found between p. 1-12 and p. 188-214 are extremely useful in the development of the "Without the Law" Jurisprudence.
} 
of transformative praxis which a human rights state envisages, the struggle for such a state must continue.

\section{REALIZING THE NEW CONSTITUTIONAL VISION}

The role of law in social transformation ${ }^{80}$ has a long genealogy when posed as a question about whether law and the courts can advance, stagnate or impede social justice. ${ }^{81}$ This question, once the source of serious and continuous jurisprudential debates, has acquired a consensus that law, indeed, has a role to play in development. It is now generally acknowledged from this debate that law has profoundly distributive effects and it cannot be ignored as a tool for social justice. ${ }^{82}$ This multi-disciplinary consensus is shared by lawyers, economists, policy makers, politicians, and international organizations and think tanks.

In the coming into effect of the new phenomenon of transformative constitutionalism, ${ }^{83}$ this debate has been both enriched and transformed (pun intended). The very idea of a transformative constitution (such as those of India, Colombia, South Africa, and Kenya) is the

\footnotetext{
${ }^{80}$ In my doctoral thesis, Relational Contract Outside National Jurisdiction (1993), supra note 72, particularly in Chapters 2and 3, I attempt to problematize the various schools of jurisprudence, including the Marxist one, on this issue. Other than staunch positivists there is a consensus that that law has a role to play as an engine of social transformation. The Marxist school still problematizes in whose interests is this social transformation. See Charles A Beard, An Economic Interpretation of the Constitution of the United States (New York: The MacMillan Company, 1913), [Republished edition, Dover, 2004].

81. Supra notes 1, 79; Morton Horwitz, The Transformation of American Law 1870-1960 (New York: Oxford University Press, 1992).

82. Ibid.

83. Supra note 1; Cass Sunstein, Designing Democracy: What Constitutions Do (New York: Oxford University Press, 2001); Yash Ghai, "Redesigning the State for 'Right Development' in Bard A Andreassen \& Stephen P Marks, eds, Development as a Human Right: Legal, Political, and Economic Dimensions [A Nobel Book] (Cambridge, Mass: Harvard University Press, 2006, new edition 2011) 141-166; Yash Ghai, "The Chimera of Constitutionalism: State, Economy and Society in Africa" in Swati Deva, ed, Law and (in)Equality: Contemporary Perspectives (Lucknow, India: Eastern Book Co., 2010) 313-331; Yash Ghai, "State, Ethnicity and Economy in Africa" in Hiroyuki Hino et.al, eds, Ethnic Diversity and Economic Instability in Africa: Institutions and Policies for Development (Oxford: Oxford University Press, 2012) 129-168; S. K. Verma Kusum, ed, Fifty Years of the Supreme Court of India: Its Grasp and Reach (New Delhi: Oxford University Press, 2000); Roberto Gargarella, Pilar Domingo, Theunis Roux, eds, Courts and Social Transformation in New Democracies: An Institutional Voice for the Poor? (Aldershot: Ashgate Publishing Limited, 2006). This extremely useful book has three chapters on theoretical analysis on social transformation followed by case studies from Hungary, South Africa, Colombia, India, Brazil, Angola and Bolivia.
} 
HUMAN RIGHTS STATES AND SOCIETIES

idea that the constitutional superstructure is embedded on a theory that it will be an instrument for the transformation of society rather than a historical, economic and socio-political pact to preserve the status quo as the earlier constitutions, such as the US or English Constitution, did.

\section{B. THE JUDICIARY TRANSFORMATION FRAMEWORK 2012-2016}

The Judiciary Transformation Framework (JTF) is the blueprint for laying a strong foundation for a transformed judiciary. The framework has four pillars: access to justice, infrastructure, transformative leadership, and the use of technology as an enabler for justice. The new judiciary that was put in pace post the enactment of Kenya's new Constitution of 2010 quickly dusted off many old reports that had recommended radical reforms in the Judiciary, but it still lacked the will to implement them. Instead, it set about implementing reforms that had already been agreed upon. This strategy was meant to nip internal resistance to the JTF in the bud. The reforms started at the margins because of a lack of political will internally and externally to transform the judiciary. In order to build public confidence in the Judiciary, it focused on reforming the prevalent judicial culture. This "judicial cultural revolution" was aimed at re-orienting that institution to serve the citizen and the court user as a client rather than lord it over them. It included sending simple messages to the public to the effect that they should begin to demand better services from the courts coupled with the basic re-training and re-immersion for judicial officers in learning the basics of public service. It included, for example, the innovation of the "six pledges" displayed on all our court stations and which every judicial officer was required to adhere to. The first two of which, human as they are, were remarkable in their absence in the “old” Judiciary: They read:

- We pledge to cordially greet you and welcome you to our courts.

- We pledge to treat you with courtesy, dignity, and respect. 
Long regarded as distant, arrogant, bewigged, and bewildering, the deliberate attempt to humanize the judiciary won public acclaim and support. Public toilets in the courts were cleaned and the practice of charging lawyers and litigants for their use stopped. ${ }^{84}$ After debate, it was agreed that judges of the superior courts would not wear wigs; ${ }^{85}$ that all judicial officers, from the Magistrates to the Supreme Court would be addressed as "Your Honour," judges were - to put it simply if metaphorically - stopped from playing God; ${ }^{86}$ the title of "judges" who committed injustices against the people was deconstructed ${ }^{87}$ as noted earlier on, a pledge from judicial officers and staff that humanized the administration of justice was created; certain innovations were introduced in respect of judicial proceedings including judgments as dialogue. ${ }^{88}$ The Judiciary was remade into a service institution for all Kenyans. Internal equity of

\footnotetext{
${ }^{84}$. In our work as judicial officers we peruse pleadings and the last prayer invariably reads: And any other relief that this honourable court deems fit to grant. We urged that access to toilets is one such relief that we should permanently give to citizens!

85. See Willy Mutunga, "Dressing and addressing the Kenyan Judiciary: Reflecting on the History and Politics of Judicial Attire and Address,” (2013-2014) 20 Buffalo Human Rights Law Review 125.

86. And the Christians supported this change! There is only one Lord and that is Jesus Christ! Resistance to this change that reflects our constitutional values of equity, equality, inclusiveness, non-discrimination and human dignity is both internal and external. Recently, a Bill in Parliament attempted to reverse this important reform without success. Such addresses have their roots in feudalism and were reflected in the structure of courtrooms that put judges on elevated platforms and pulpits. And the language of pleadings and addresses by lawyers were couched in the language of prayer, for example "My Lord, my prayers this morning are!"

87. Upon the Supreme Court deciding against the petitioners in a presidential election in 2013 an enraged Kenyan called me Mr. Chief Injustice! This triggered the reflection stated here about demystification and deconstruction and the realization that certain addresses rationalize injustice.

88. The pledge included welcoming litigants to court, keeping eye contacts with litigants and accused persons; allowing litigants and lawyers to walk out of the court to use bathrooms, and developing what we have come to call "judgments as dialogue" in line with the constitutional value of accountability. Judgments as dialogue addresses the loser in any cause in a concerted attempt to convince them that they had justice. This is done through the change of style and format of judgments that focuses primarily on the loser, giving them clear reasons why they lost and why the other party one in a language they understand. Our judgments and their format and style tend to a singular dialogue with the lawyers as a medium of explaining the outcome to their clients. This role is no longer one of counsel who in the Kenyans experience may not communicate the essence of the outcome as honest feedback. The use of short media briefs, borrowed from the Constitutional Court of South Africa, is an important ingredient of judgments as dialogue.
} 
HUMAN RIGHTS STATES AND SOCIETIES

voices was horizontalized through a process of inclusion. A "Tea Drinking Social Movement" was started. ${ }^{89}$

With the ushering of a cultural revolution in the judiciary, drinking tea was democratized and all staff in the Judiciary in all court stations were henceforth entitled to tea; something that had hitherto been a preserve of the heads of stations and their secretaries. The internal resistance to this policy, though understandable given the power dynamics around access to tea, remains one of the most bewildering aspects of our transformation. ${ }^{90}$ This central question became a watchword: How could judicial officers and staff convince Kenyans that they would receive justice if they could not give the same to their own colleagues.

Monthly tea sessions, which included the Chief Justice, staff, and judges, started at the Supreme Court. There was an important lesson here: giving the rank-and-file within the institution a voice and dignity to speak up and participate in the governance of the institution locked them into the transformation ideology; giving them a stake; and insuring against backsliding by their seniors. By delivering colleagues from administrative tyranny; whimsical and undemocratic transfers across court stations in the country; stagnated promotions; "sexuallytransmitted" promotions (STPs); and crafting a robust anti-sexual harassment policy, gave everyone a reason to believe in an institution that could stand for their rights and justice; and they reciprocated by serving the citizen better; and finding innovative solutions to their local problems.

The move to rid the judiciary of corruption did encounter the resistance of corrupt cartels inside and outside the Judiciary. As such, the struggle to make the Judiciary a beacon for anti-

\footnotetext{
89. It is, indeed, difficult for those who are not Kenyans to understand why this is an important transformative practice. Suffice it to say that drinking tea is deeply embedded in Kenya. Access to this socio-cultural good was underpinned by power dynamics in Judiciary.

90. Judicial officers have accepted that they are missionaries for justice and that human dignity is a value in the Constitution they have sworn to uphold. It says a lot about our humanity to begrudge our colleagues tea.
} 
corruption continues. It is worth noting that some reforms that have become irreversible, irrevocable, indestructible, and permanent. These reforms have made the Judiciary a beacon of transformation for the other arms of government, state organs, civil society, and the country at large. They remain striking and glaring examples of how to breathe life into the implementation of the Constitution. The reforms include promoting colleagues on merit and in a transparent and accountable manner; equalizing salary disparities to reflect the values of equity and equality; making training and travel fair and just; having in place transfer policies, that are authored by staff, fair and just. ${ }^{91}$ making access to insurance for all; granting access car and house mortgages to all; guaranteeing the pivotal position of JTI; entrenching the existence of Judges and Magistrate's Association and Judicial Staff Association that participate in the governance of the Judiciary; ensuring that the administrative arm of the judiciary facilitates the judicial arm which in turn ensures the core business of administering justice is not jeopardized; democratizing governance in the judiciary as decreed by the constitution; ensuring that the development of progressive jurisprudence is on course $;{ }^{92}$ making regular the project of "judgment as a dialogue" where judicial officers seek to convince the loser that they gave them justice; and creating a vibrant judicial and public constituency to make sure that these reforms are permanent.

Despite resistance from judicial officers and staff, the Office of the Judiciary Ombudsperson that receives and acts on complaints against judicial officers and staff has become a critical institution and its establishment is now all but irreversible. It has helped restore

\footnotetext{
${ }^{91}$. Judicial officers and staff sometimes forget that the old judiciary transferred them at the drop of a hat and now we have a transfer policy that respects them and which has all ingredients of due process.

92. This can be gleaned from the decisions of the divisions of Constitutional and Human Rights and Judicial Review in the High Court (in particular), and also from Supreme Court decisions on devolution and the mainstreaming of the theory of interpreting the 2010 Constitution; and isolated decisions by judges in the stations outside Nairobi. The Supreme Court will in the near future rule on integrity and leadership, land, death sentence, and various aspects of human rights and social justice jurisprudence. These decisions relate to the critical features and structure of the Constitution and will definitely determine the course of socio-economic, political and cultural progress in the country.
} 
HUMAN RIGHTS STATES AND SOCIETIES

much public confidence in the Judiciary, as have the Court Users Committees (CUCs) that were set up, which are now cradles of public participation in judicial affairs and judicial accountability. CUCs are grassroots structures reflected at the centre by the National Council for the Administration of Justice (NCAJ). The NCAJ is decreed under the Judicial Service Act. NCAJ and CUCs are the centres of inter-agency dialogue, collaboration, coordination, and interaction. They reflect the vision of the Constitution that decrees robust independence of judicial and other institutions, but calls for dialogue and inter-dependence for the public interest and good to nurture nationhood in Kenya.

The Judiciary has been a leader in the promotion of dialogue, interdependence, and collaboration as decreed by the Constitution. Although the three arms of the state are robustly independent under the Constitution, the Constitution decrees dialogue among them in the national interest. These dialogues have taken place through the Judiciary Training Institute workshops between the Judiciary and security agencies, Parliament, constitutional Commissions, and other state organs. The NCAJ is a vehicle for such dialogue. Tripartite dialogues between the President, the Speakers, and the Chief Justice have taken place on ad hoc basis should be institutionalized. In these meetings the Judiciary has been able to clarify to the other arms what it does, can do, and cannot do. It has sought to clarify the mandates of the three arms, the sovereignty of the people, checks and balances, and the supremacy of the Constitution. Through such dialogues mental shifts in favor of the implementation of the Constitution are taking place notwithstanding the resistance.

The de-marginalization of the Kadhi Courts and their continued expansion in areas where Muslim communities live has been an important reform. The Kadhis have been mainstreamed in our judicial system thus creating equity and equality in the administration of justice. The Kadhi 
Courts have been the teachers of other courts in our judicial cultural revolution. The Kadhi Courts provide the greatest proximity, humanity, and dialogue to the litigants. The Kadhi does not impose his (we do not yet have women Kadhis) status on the litigants and gets to know the Muslim community he works in by constant contacts in places of worship and community projects. The traditional justice systems and their courts will be a welcome addition to Kadhi Courts.

As importantly, but on another note, we have used scientific data in aid of the constitutional principle of accountability. Article 10 of the Constitution requires all State Organs, of which the Judiciary is one, to apply the national values and principles of governance enumerated thereunder, in the execution of their mandates. Article 10 (2) (c) in particular identifies 'good governance, integrity, transparency and accountability' as part of the body of these principles of governance. Partly in furtherance of these constitutional provisions the Judicial Service Act 5(2) (b) provided that, every year, the Chief Justice is required to prepare the State of the Judiciary and the Administration of Justice Report (SOJAR), present the report to the public; present it to the National Assembly, and to the Senate for debate and approval; and to have the report gazetted.

Even though the accountability requirements of this statutory provision are clear, the methodology remains a work in progress. There was the necessity and utility from the inception of measuring performance. That is why the Performance Management Directorate was set up as a fully-fledged directorate. Its positive impact on the transformation program, especially on data gathering perspective, has been remarkable. The process of preparing the first two State of Judiciary Reports revealed the centrality of data as a key driver of transformation. The empirical data and evidence served to illuminate performance, the lack thereof, and provided a scientific 
HUMAN RIGHTS STATES AND SOCIETIES

basis for the allocation of resources and policy decisions - decisions previously made on the basis of 'felt-needs', mere observation, or past practice, referred to by economists 'path dependency.'. In its assessment of the outputs of courts, judges, magistrates, and other judicial staff it has engendered internal and external accountability. The internal leadership of the Judiciary is now more accountable in administrative decisions that are expected to be evidencebased. Data has emerged as the king of transformation. Its neutrality and fairness leaves very little room for quibbling.

Deepening the culture of data gathering and performance reporting institutionalizes accountability, induces performance through competitive and comparative tendencies, and secures transformation permanently. To entrench accountability practices as part of transformation, an expansive view of the provisions of the Judicial Service Act is necessary. Whereas the law envisaged only a national level report to the Legislature, it was necessary to require station-based reports where judicial officers at the court level and immediate consumers of judicial services at the grassroots could see the performance of their courts. The station-based reports are still in their infancy and the next state of the judiciary report will have a more robust design, structure, and variables. It will include the number of cases filed, cleared and pending, financial information on the budget of the station, the amount of resources actually allocated to the individual court in every financial year for court and $\mathrm{CuCs}$ work, and the amount of monies held as deposits. Suffice to say that as detailed as the State of Judiciary Reports have been, and in a clear breach of the law, both houses comprising the Legislature have not debated them. The third report is due to be presented shortly and the fourth one before the end of this year.

The Kenyan case confirms that the implementation of devolution of political power and resources is ushering in the politics of issues, the central one being the equitable distribution of 
resources. Kenyans are seeking greater participation in how the resources received in counties are spent by the Governors and the Members of the County Assemblies. They want to be involved in the prioritization of projects and public participation at the grassroots is growing. At this level the vision of the constitution that all political and public power is derived from the people of Kenya, and thus the very first attempt to bring the state and its apparatuses under the sovereignty of the people is being made. This great movement of the people is challenged by the crisis of political leadership that focuses on the politics of divide and rule invoking ethnic, religious, regional, class, generational, gender, clan, and racial divisions to keep the political elite in power. What is worse is the lack of a visible organized alternative political leadership. The middle class civil society leadership still debates the principle of non-partisanship when their grassroots compatriots are debating the formation of political parties that will be anchored on transformative social movements. So, there is a great movement developing at the grassroots because of resources are being directed there absent an alternative political leadership take political advantage of them. There is still a great opportunity in Kenya for an alternative political leadership to contest political power on a manifesto based on the vision of the transformative constitution. A humanized state that has a social democratic content is possible. The devolution of political power expands the sovereignty of the people ${ }^{93}$ that can be a basis of the deepening our transformation. ${ }^{94}$

\footnotetext{
93. Dr. David Ndii has authored articles in the Daily Nation, Nairobi, Kenya in praise of devolution. It is a pity alternative leadership in Kenya is sleeping through this revolution!

${ }^{94}$. See John Bellamy Forster, "Chavez and the Communal State: On the Transition to Socialism in Venezuela" in (April 2015) 66:11 Monthly Review 1-17. This is a great analysis on how the state can be brought under the sovereignty of the people, the resistance from internal and foreign forces, the role that political leadership has to play in the promotion and protection of the sovereignty of the people. For Kenya this is an opportunity to rethink devolution of political power and whether the implementation of the constitution is a basis for more qualitative and fundamental restructuring of the society. It may be our contribution to the search of paradigms that will liberate Kenya and the world.
} 
HUMAN RIGHTS STATES AND SOCIETIES

\section{CONCLUSION}

The history of human rights and social justice paradigms in the African context has been richly documented. ${ }^{95}$ The usefulness and limitations of these paradigms in social transformation can be gleaned from positions taken by five of East Africa's distinguished professors. ${ }^{96}$ There are two contradictory human rights and social justice approaches that impact the fundamental question of transformation. Historically, rights have been both revolutionary and conservative. Rights themselves become terrains of struggle, with different groups offering alternative conceptions of rights. ${ }^{97}$ It is important to recognize the counter-hegemonic discourse within human rights framework notwithstanding its Euro-centeredness in origin and orientation. For such analysis to be useful we must understand the contemporary global context within which these paradigms operate.

It is the argument of this paper that the ideological, political, and intellectual positions advanced by Issa Shivji ${ }^{98}$ Eric Hobsbawm, ${ }^{99}$ Samir Amin, ${ }^{100}$ and Rosa Luxemburg ${ }^{101}$ represent the correct position within the contemporary global context. Issa Shivji's work on the limitations of human rights is well documented. Hobsbawm simply states, "Our world risks both explosion and implosion. It must change." 102 Within the context of Africa and Global South this "World" is one of domination, oppression, exploitation by Western contemporary capitalism. Although in some part of the Global South there are signs of gradual disengagement from world

\footnotetext{
95. Supra note 5.

${ }^{96}$.Ibid, Professors Yash Ghai, Issa Shivji, Mahmood Mamdani, Joe Oloka-Onyango and Makau Mutua.

${ }^{97}$.Ibid.

${ }^{98}$. Ibid; His analysis of the limitations of human rights has although been discussed above when I discussed the conceptualization of human rights.

99. The Age of Extremes: A History of the World, 1914-1991 (United States: Vintage Books, 1996).

100. The World We Wish To See: Revolutionary Objectives In The Twenty-First Century (New York: Monthly Review Press, 2008); The Implosion Of The Contemporary Capitalism (New York: Monthly Review Press, 2013).

${ }^{101}$. Reform or Revolution, Manifesto: Three Classic Essays On How To Change The World (Australia: Ocean Press 2004).

102. Supra note 80 at 585.
} 
contemporary capitalism that is not the case for Africa and many states in the Global South. ${ }^{103}$ Samir Amin on the other hand in analyzing what he calls the "tragedy of great revolutions" argues thus:

The "great revolutions" are distinguished by the fact that they project themselves far in front of the present, towards the future, in opposition to others (the 'ordinary revolutions'), which are content to respond to the necessity for transformations that are on the agenda of the moment." 104

Rosa Luxemburg argues that "for Social Democracy there exists an indissoluble tie between social reform and revolution. The struggle for reforms is its means; social revolution, its goal. ${ }^{105}$ She also argues "in effect, every legal constitution is a product of a revolution. ${ }^{106}$ It is on the basis of these theoretical and practical theses that persuade the author, as he has previously argued, that:

I believe using human rights to interrogate the paradigms of capitalism, socialism and communism may be the basis upon which we discern the appearance of another utopia. The quest for a new world that the World Social Forum argues is possible, will also require the search for a utopia, a paradigm that will be the ideological, intellectual and political anchor of this new world. ${ }^{107}$

It is also on the basis of the here and now that the author has argued that transformative constitutions and their transformative constitutionalism that anchor the consolidation of human rights states ${ }^{108}$ and societies can mitigate current status quos in societies that are unacceptable and unsustainable. ${ }^{109}$ Such progressive and transformative constitutions are, indeed, "ordinary

\footnotetext{
${ }^{103}$. Ed., Kwesi K Prah, Afro-Chinese Relations: Past, Present and Future (Cape Town: CASAS, 2007).

${ }^{104}$. Supra note 81 at 17.

105. Supra note 99 at 71.

${ }^{106}$.Ibid at 128. See, Antonio Gramsci, Selections from the Prison Notebooks of Antonio Gramsci (New York: International Publishers, 1971) xvii: "The notion that social-democracy was the "left wing of the bourgeoisie" had been generally accepted, for example, by Italian communists since Zinoviev first put it forward in 1922." Contemporary politics in countries ruled by social democratic parties in Europe has shown that there are more than one strands of social democracy, see-sawing between conservative and radical social democracy.

107. (2012) 30:4 Nordic Journal of Human Rights 520.

108. I have defined it as a variety of a radical liberal state that has a radical social democratic content.

109. Willy Mutunga, “Kenya: A New Constitution,” (2013) Socialist Lawyer 65, 20
} 
HUMAN RIGHTS STATES AND SOCIETIES

revolution" or "product of a revolution" and they can be the basis of fundamental restructuring or revolution of states and societies. ${ }^{110}$

Transformation as the Kenyan case study shows is at two levels, the theoretical or visionary level and at the level of implementation. At the first level the vision of the constitution is clear as a manifesto for change and social progress. At the implementation level ideological and political struggles abound. The Kenyan Judiciary's experience of reforms from the margins to the centre is useful. It is testimony that reforms can actually take place in regimes that are antireform if the leadership of an institution is ready to struggle for them. It does not matter that positive outcomes are not readily discernible. The idea is to get the sovereignty of the people, that is, their material interests reflected in the reforms and they will provide the necessary support. A striking example is one of the irreversible outcomes in the implementation of devolution in Kenya. As resources get to the counties, rural towns and villages, particularly in areas that have been marginalized, the support of the citizens will be strengthened. Alternative political leadership will grow from these hitherto marginalized counties because the citizens will not allow their resources to be stolen.

The obvious must, however, be stated. Even with progressive Kenyan jurisprudence based on our transformative constitution, what is now called the gospel according to the Africans, it must still be must conceded that the project of transformation is fundamentally a political one. If the Judiciary had irreversible support from the political elites much progress could have been made at a quicker pace. The fundamental question of who will control the human rights and social justice state in Kenya will not go away. The struggle for alternative political leadership in Kenya will not go away. Should such political leadership emerge, mobilize

\footnotetext{
${ }^{110}$.The implementation of such constitutions and their outcomes reflect struggles between the vested interests of the status quo and those of the progressive forces.
} 
on the basis of the implementation of the constitution and capture power, then proceed to implement the constitution there is no doubt that Kenya's social transformation would be put on a social democratic trajectory, a definite social progress.

This theoretical and practical approach remains politically plausible to the interrogation of this critical contemporary question, namely, whether the paradigms of human rights and social justice can be a basis for fundamental restructuring and transformation of Kenya. The question of who controls human rights remains key in the reconceptualization of human rights. The question impacts the success or failure of transforming institutions created under transformative constitutions. Undeniably, in the end, all these issues raise fundamental political questions whose answers will be the fundamental ingredients of political manifestoes of Kenyan social movements and the political party that is ideologically and politically committed the vision of transformation. 